\title{
Collective Action for Territorial Identity in Tourism: The Case Study of Two UNESCO Sites
}

\author{
Alessandra Storlazzi ${ }^{*}$, Darija Lunic ${ }^{* *}$, Roberto Micera***
}

\begin{abstract}
An innovative approach not developed in management and valorisation of tourist destinations yet considers tourism heritage and related territorial identity as a common and brings attention to the implication of the logics of self-organised and self-governed collective action of the common theory applied to territorial governance. The analysis of two case studies of two UNESCO sites is developed: the Cilento, Vallo of Diano and Alburni National Park and the city of Venice. The first represents a case of territorial domain identity characterised by collaborative governance and the second is characterised by uncooperative governance.

The theory of commons and self-governed collective action applied to the two cases contributes to the definition of new research pathways and suggests innovative management strategies.
\end{abstract}

Keywords: Commons Theory; Territorial Identity, Collective Action, UNESCO; Global Tourism; Tourism Destination

\section{Collective Action for Tourism}

The issue of territorial tourism development has recently been widely addressed. Many researches have focused on the topic of tourism destination and have defined it from different perspectives (Corti 2016, Brondoni 2011, Brunetti, 2002, Buhalis, 2000). Some studies have focused on economic content of tourism destination. Other studies have framed the theme of tourism destination in a competitive marketing position logic consistent with marketing management and thus introduced concepts such as life cycle of tourism area (Butler 1980), destination brand and destination marketing. The development of the theme of destination tourism has thus led to the introduction of a holistic approach. In territorial area the existence of a multipartnership encourages development of a variety of strategies but, at the same time, on the other hand, it determines fragmentation which makes definition of a unitary system of offer and shared strategic proposal more complex. This paper deals with the theme of territorial tourism development in an innovative perspective. The

\footnotetext{
* Associate Professor of Management, University Suor Orsola Benincasa (alessadnra.storlazzi@unisob.na.it)

** Lecturer in Tourism Management, Univerzitet Singidunum (dlunic@ singidunum.ac.rs)

**** Institute for Research on Innovation and Services for Development (IRISS), National Research Council (CNR) (r.micera@iriss.cnr.it)
} UNESCO Sites, Symphonya. Emerging Issues in Management (symphonya.unimib.it), 3, 81-96. 
territorial resources are considered as commons relate to the identity domain framework (Livengood \& Reger, 2010). From this it is the domain identity that aggregates subjects which helps defining the territorial supply and creates relationship between stakeholders. Shared perception of a common identity determines identification of a territorial resource as a one. The contribution of the paper is that it draws attention to the logics of self-organised and self-governed collective action of the common theory applied to territorial governance. The analysis of two 'extreme' case studies of two UNESCO sites has been carried out: the Cilento, Vallo of Diano and Alburni National Park and the city of Venice. The first one represents a case of territorial domain identity characterised by collaborative governance, while the second oen is characterised by uncooperative governance.

The contribution first reflects the debate on the community governance process and commons (par 2) and it focuses on territorial tourism identity as a common (par 3). Then it focuses on the governance pathways of self-governed collective action inherent in the theory of common (par 4). The interpretative framework developed is used for the in-depth analysis of two case studies (par 5). Finally, some conclusive considerations are presented (par. 6).

\section{The Process of Community Governance: The Territory as a Common}

As it is common knowledge, commons represent goods whose consumption is open to all but whose stock is progressively reduced due to rivalry in consumption (Ostrom, 1990). In recent years, an intense international debate has emerged about the need to get rid of the binary logic of public property - private property, to reach a three-partition that includes as a third element the common meant as something to be used in favor of the community yet not to be owned individually. Despite commons are present everywhere they are difficult to be defined. The theory distinguishes two categories of commons. A first category includes: water, land, forests and fishing, namely the livelihoods on which life depends, particularly the one of farmers, fishermen and natives living directly through natural resources, but also biodiversity seeds selected over the centuries by local populations, the genetic heritage of man and of all species of plants and animals, global commons as the atmosphere, the climate, the oceans.

A second category of commons includes intangible resources such as knowledge, social trust, solidarity, security, and peace and so all those goods that are the result of collective creation of a community and whose use must be regulated (Ostrom, 1990). Someway, in the industrialised societies, the commons category has assumed an important value.

Commons Theory is linked to the Common Property Governance Theory (Manfredi, 2013). From the physical aspect, the territory is a traditional common good that falls into the first category. It is also characterised by accumulated knowledge linked to local traditions and specific social capital, so it could represent new commons.

Recently, an emerging evolutive framework known as Community Governance has investigated the relationship between territorial dimension, community quality, social capital and effectiveness of government processes (Manfredi, 2013).

The community forms a true governance structure. In practice, continuous relationships within community produce trust and mutual support. 
In fact, the Community Governance includes strong participation of legitimate citisens in decision-making process. In this way, citisens produce social capital providing solutions to community problems.

The Community Governance monitors behavior of its members by making them responsible for their actions. It is able to produce and use intangible resources that represent incentives people have always used to regulate collective activities: trust, solidarity, reciprocity, reputation, personal pride, respect and social esteem.

The framework which is defined as Community Governance seems to be able to recognise the self-organised collective action of the government of common goods. As with the governance of common goods, the concept of social governance is derived in contrast to the hierarchical and bureaucratic structure of the government. It creates a decentralised decision-making process where value is placed on the participation of citisens (Manfredi, 2013).

The democratic control of the territory by local communities assigns them a role in the qualification of territory as common.

In this way, the most right way to translate commons is «communities» because it holds together goods, rules of use, and communities of reference. The community becomes the collective subject of self-government of common goods, and assumes different names and connotations in different places and in different historical periods. The community is the exact opposite of the market, in the sense in the community the abstract dimension of market relationships is not important, but the concrete dimension of interpersonal relationships that respond to the need for communication and sociality inherent in man are. In the event of difficulties, the social group is to determine which ones are collective goods, private goods, commons. One good can be considered differently depending on the group that makes use of it. Individuals who establish even a small social relationship are involved in the debate of what the relationship is and how it should be managed, thereby gaining legitimacy of commons sharing or collective natural spaces and resources that are appropriated and managed by the group in accordance to shared standards. Commons therefore form as open receptive adapters to the premises. The recovery of community rights over commons, their re-utilisation of natural resources, represents a new paradigm of a society organised at a local level and with a democratic, ecologically sustainable. The new paradigm is integrative and partially replacement of the market. A proper management of commons requires therefore a change of dominant economic paradigms and a change of mentality. So it's needed to find, through the shared management of commons, the community's ability to cooperate in harmony (Ostrom, 1998). The most right way to translate commons is 'communities' because it holds together goods, rules of use, and communities of reference. The community becomes the collective subject of self-government of common goods, and assumes different names and connotations in different places and in different historical periods. The community is the exact opposite of the market, in the sense in the community the abstract dimension of market relationships is not important, but the concrete dimension of interpersonal relationships that respond to the need for communication and sociality inherent in man are.

In the current crisis of capitalism, the community can represent both a garrison in the territory and an instrument of democratic participation of the population in the choices that affect it. In any case, according to Ostrom's theory of governing the commons (Ostrom, 1990), territorial resources seem to be able to define common goods and the subjects that manage them are called 'principals', they are 
interdependent among themselves, they can self-organise and self-rule in order to obtain collective benefits over time, overcoming the temptation to exploit resources or otherwise to act opportunistically.

Ostrom's theory has thus formulated eight organisational principles that are selfgoverning logic and that when adopted by a community of related subjects, manage to create the conditions for good governance of the common good (see Table 1).

\section{Table 1: Organisational Principles of Ostrom's Theory}

\begin{tabular}{|c|c|}
\hline $\begin{array}{l}\text { 1. Define clear group } \\
\text { boundaries. }\end{array}$ & $\begin{array}{l}\text { Individuals and families, who have the right to withdraw certain units of the } \\
\text { common resource, must be clearly identified. This is to ensure that those who } \\
\text { contribute to the management of the good are certain that their efforts will not } \\
\text { be frustrated by the action of outsiders nor will they be allowed free-ride } \\
\text { behaviors. }\end{array}$ \\
\hline $\begin{array}{l}\text { 2.Match rules governing } \\
\text { use of common goods to } \\
\text { local needs and } \\
\text { conditions. }\end{array}$ & $\begin{array}{l}\text { The rules, whether regarding the supply or the supply of the common, must be } \\
\text { specific to the environment they govern. For this reason, it is necessary to } \\
\text { establish different regulations for different systems }\end{array}$ \\
\hline $\begin{array}{l}\text { 3.Ensure that those } \\
\text { affected by the rules can } \\
\text { participate in modifying } \\
\text { the rules. }\end{array}$ & $\begin{array}{l}\text { Because self-government works, it is necessary that most individuals, on whom } \\
\text { the operating rules are expressed, have the ability to modify these rules, also in } \\
\text { order to adapt them to contextual specificities and systemic changes that } \\
\text { intervene in it. }\end{array}$ \\
\hline $\begin{array}{l}\text { 4.Develop a system, } \\
\text { carried out by community } \\
\text { members, for monitoring } \\
\text { members' behavior. }\end{array}$ & $\begin{array}{l}\text { Audit systems must be implemented. Moreover, members of the community } \\
\text { must be accountable both to controllers and the whole community. }\end{array}$ \\
\hline $\begin{array}{l}\text { 5.Use graduated } \\
\text { sanctions for rule } \\
\text { violators. }\end{array}$ & $\begin{array}{l}\text { Punishment must be highly probable, even if graduated, for those who violate } \\
\text { the operating rules. It is necessary to trigger almost-voluntary compliance in } \\
\text { the sense that compliance with the rule must be almost without coercion, but } \\
\text { through the so-called contingent behavior. }\end{array}$ \\
\hline $\begin{array}{l}\text { 6.Provide accessible, } \\
\text { low-cost means for } \\
\text { dispute resolution }\end{array}$ & $\begin{array}{l}\text { The presence of some mechanism to establish what constitutes an infringement } \\
\text { is indispensable to avoid conflicts within the user group; }\end{array}$ \\
\hline $\begin{array}{l}\text { 7.Make sure the rule- } \\
\text { making rights of } \\
\text { community members are } \\
\text { respected by outside } \\
\text { authorities. }\end{array}$ & $\begin{array}{l}\text { Once the community members have committed themselves to a contingent self- } \\
\text { commitment, then these will be motivated to monitor themselves the behavior } \\
\text { of other members (peer review). }\end{array}$ \\
\hline $\begin{array}{l}\text { 8.Build responsibility for } \\
\text { governing the common } \\
\text { resource in nested tiers } \\
\text { from the lowest level up } \\
\text { to the entire } \\
\text { interconnected system. }\end{array}$ & $\begin{array}{c}\text { Those who use or use the common resource, suppliers, controllers, executive, } \\
\text { dispute resolution bodies, and those administering governance should all be } \\
\text { organised through multiple layers of companies or organisations organised on } \\
\text { multiple levels . }\end{array}$ \\
\hline
\end{tabular}

Source: Ostrom, 1990, 1998.

Considering territorial resources as commons relates to the identity domain framework (Livengood \& Reger, 2010). It is the domain identity that aggregates subjects that help defining the territorial supply and which creates a relationship between the territorial stakeholders. It is the shared perception of a common identity that determines the recognition of the territorial resource as a common good. The local community that participates in the governance process of the territorial tourism offer the territorial domain of identity as a factor of aggregation and consequently as a new common. 
A clear, strong and shared territorial identity generates legitimacy and determines aggregation, while the territorial domain of identity generates the territorial community.

\section{Territorial Domain of Identity and Common Domain of Identity}

The topic of organisational identity is rooted in the debate about the territorial identity. The issue of territorial organisational identity considers the concept of territorial identity (Roca et al., 2007), linked to the uniqueness, singularity, specificity and authenticity of the resources present on a particular territory.

According to these Authors, the concept of territorial identity can be deepened, articulated, considering two point of views: spatial fixes and spatial flows.

The first elements are: natural heritage, population, human-made economic heritages, human-made cultural heritage (Zan et al., 2013). Spatial flows are the activities and relationships that are realised on the territory to constitute nature, society, economy and culture.

In this framework we introduce the concept of common domain of identity that represent the factor of aggregation of territorial resources. It is the basis for connecting with Ostrom's Theory and relies on the consideration of territorial resources as common goods.

The existence of a resource variety that makes up the territorial supply system (Zan, Baraldi, 2013). involves the existence of this multi-partnership and determines fragmentation which places the territorial identity at the center of the definition of a unitary offer system.

Organisational identity has been defined as "the members' consensual understanding of who we are as an organisation" (Fiol, 2001). Some theorists, who have analysed organisational identity in the strategy field, are convinced that organisational identity facilitates the pursuit of a unified strategic plan.

This theory attempts to bridge the gap between organisational identity theory and competitive dynamics by introducing a new concept, identity domain, in order to explain why firms compete vigorously in some competitive arenas. The organisation's identity is how the firm sees itself, whereas the identity domain is the competitive arena that best captures and reinforces this sense of identity.

In fact, the origins of Identity Domain Theory are in the Organisational Identity streem, that has long been recognised as a significant concept in organisational studies (Brown, 2001), but has recently received increased attention in management studies as a root construct of growing importance (Albert et al., 2000). Numerous studies have defined what organisational identity is and why it matters (Albert et al., 2000; Dutton \& Dukerich, 1991; Gioia \& Thomas, 1996; Whetten \& Godfrey, 1998), but its core definition considers central, enduring, and distinctive characteristics. The central character of the organisation is rooted in the «more or less internally consistent system of pivotal beliefs, values, and norms, typically anchored in the organisational mission that informs sense-making and action» (Ashforth \& Mael, 1996, 1989). Some theorists have also analysed organisational identity in strategy field according to a resource-based approach, introducing a new vision of identity like a resource to gain a competitive advantage (Fiol, 1991, 2001).

The formulation of a shared territorial identity domain promotes development 
process and it constitutes an aggregative factor of different stakeholdes that present in a geographical area and interested in its development.

Consequently, Identity Domain framework (Livengood \& Reger, 2010) can be a factor of aggregation of territorial community, thus facilitating strategic governance.

\section{Territorial Governance and Self-governed Collective Action}

In territorial area the existence of a multi-partnership encourages the development of variety of strategies but, at the same time, on the other one, it determines fragmentation which makes more complex the definition of a unitary system of offer and a shared strategic proposal. Considering territorial resources as commons relates to the identity domain framework (Livengood \& Reger, 2010). It is domain identity that aggregates subjects helping to define territorial supply and which creates a relationship between the stakeholders. 'communities' because it holds together goods, rules of use, and communities of reference. It is the shared perception of a common identity that determines the identification of the territorial resource as a common. The local community that participates in the governance process of the territorial tourism offer shares the territorial domain of identity as a common and consequently as a factor of aggregation (Manfredi, 2013). Furthermore, the process of territorial governance considered as a set of coordinating and monitoring activities, enables the survival of the collaborative partnership or institution (Bryson et al., 2006) and induces paths of progressive convergence towards shared objectives. Territorial governance is linked to the ability to foster participation and invokes focus on the role of public bodies, on the participation of citisens and businesses. The concept concerns the ability to promote dialogue and to develop credible policies capable of deploying many players in society and encouraging them to take the risk of change. The evolution of issue of territorial governance can be approached as collaborative governance considered as the processes and structures of stakeholders and public policy decision making across the boundaries of public agencies, levels of government, and/or the public, private and civic spheres, in order to carry out a public purpose that could not otherwise be accomplished (Olson 1965, Emerson, Nabatchi \& Balogh, 2012; Brondoni, 2010). Multi-partner governance, likewise, includes partnerships between the state, the private sector, civil society, and the community, as well as joint government and hybrid arrangements such as publicprivate and private-social partnerships and co-management regimes (Agrawal \& Lemos, 2007). The community at all levels within the logic of collaborative governance (Olson, 1965) plays a crucial role in defining and implementing innovative paths of value creation, citisens are closely related to the territorial area and are the players operating there (Brondoni \& Franzoni, 2016). Even for a touristoriented area, it is equally feasible that the perception of the identity characters of the tourist vocation is the determining element that aggregates strategies and choices of the subjects that make up the area's offer. "The quality of a city's tourism offer is not only constituted of hotels, restaurants and museums, but expresses the quality of life of its citisens, the level of security, environmental quality, the variety and specificity of services, cultural accessibility" (Brondoni \& Franzoni, 2016). When the territorial area has a tourist vocation it becomes a tourist destination as a whole. If the conditions of a shared identity perception and of a self-organised collective action 
are also there, it becomes characterised by being a common of the subjects exercising the territorial governance together (Bellini, 2004).

In this sense destination management and territorial governance have close links. The development of destination management has thus led to the introduction of a holistic approach and, as noted (Presenza et al., 2005), the holistic conception makes the managerial capacity to coordinating the strategies and choices of subjects that contribute to characterising the destination.

In this context, moreover, destination management assumes the central role of the subjects that through the mutual co-ordination of their action give value to the territorial resources and exercise territorial governance together. Territorial governance is therefore a central concept of destination management. It involves partnerships, agreements, cooperation, self-regulation and social responsibility, which generally affect any public administration, institutions, residents, enterprises whose focus is on value creation.

The acknowledgment of a strong shared territorial identity can be the starting point of a process of autogovernance of territorial development.

\section{Tourism Destination Area and Commons: An Analysis of two Extreme Case Studies}

The empirical phase of our research has been developed through a qualitative study of two cases considered extreme (Yin, 2003; Mills et al.,2010). The extreme cases approach is employed when the purpose is highlighting the most unusual variation in the phenomena under research rather than telling something typical of the population in question (Seawright, 2015; Baskarada, 2014; Seawright \& Gerring, 2008). In this way it is possible to reveal more information because the cases activate more actors and basic mechanisms in the studied situation (Baxter \& Jack, 2008; Flyvbjerg, 2006).

The data collection method envisages both the consultation of many documents obtained through websites and open interviews with some main key informants of the investigated territories.

The contribution analyses the experience of the Cilento, Vallo of Diano and Alburni National Park which is one of the largest Italian Parks in terms of extension of the area and of number of municipalities and the case of the city of Venice which is one of the most worldwide known and visited cities. These can be defined as extreme cases, because despite of the fact that they are Unesco World Heritage Sites for organising composition of the productive tissue and social structure are diametrically opposed.

The Cilento and Vallo of Diano and Alburni National Park is the second national park in Italy for dimensions, with an area of about 181,048 hectares. This Park includes 95 Municipalities, defined autonomous administrative areas as intense as delimited by territorial boundaries.

Since 1998, the Cilento and Vallo of Diano and Alburni National Park is a Unesco World Heritage Site (with the archaeological sites of Paestum and Velia and the Certosa di Padula); since 1997 it is a Biosphere Reserve; since 2010 it is the first italian national park to become Geopark.

Venice is the first municipality in the region of Veneto, both for population (264.015 inhabitants on September 2015) and for surface, extending for 414 sq. Km. 
Being composed of more than $60 \%$ of water, the territory of the City of Venice is very articulated and particularly complex. It is characterised by: the lagoon and archipelago of islands, the ancient city of Venice on water, the mainland which in turn includes Mestre, Marghera (the industrial zone and the urban district) and some smaller municipalities aggregated at the beginning of ' 900 .

Since 1987 the city of Venice is an Unesco World Heritage Site. Venice and its lagoon has been one of the first Italian sites to join the list of Unesco recognised goods. From a touristic point of view Venice is one of the art cities with more tourist flows throughout Italy, concentrated in a very small space, we are referring mainly to the historical center of the city and, more specifically, only to some small districts, the most important ones, that are crossed by most tourists every day.

Following the reconstruction of the theoretical framework integrating territorial identity domain and commons theory based on autogovernance principles we develop the research questions. The research questions are:

- Have the territorial resource and local actors in the cases study developed a strategic collaborative governance?

- Does the Cilento, Vallo of Diano and Alburni National Park and Venezia city focus strategic attention on its specific territorial identity domain?

- How Cilento, Vallo of Diano and Alburni National Park and Venezia city see the territorial identity domain as a common?

To develop the research questions, the empirical work has focused on a qualitative study of the case of the Cilento, Vallo of Diano and Alburni National Park and of the case city of Venice.

Starting from the theoretical framework and assumptions, we develop the cases studies to consider the first point: Have the territorial resource and local actors developed a strategic collaborative governance?

The Italian National Parks system adopts, in fact, a strategic collaborative governance. In Italy the policy of natural areas and the law establishing the National Parks (Law no. 394/1991), seek to promote innovative action planning. Focused on collaborative governance, the law emphasises the importance of integrating various players and projects by pursuing strategies centred on the appeal of the areas, its services and environment. The purpose is the sustainable development of the territory (Pattaro \& Pistocchi, 2016; Salvioni \& Astori, 2013). The latter, in turn, facilitates the welfare of local communities and users, which also means taking into account the protection of future generations. In short, the sustainable development of the territory, in conformity with the declared purposes of Italian National Parks, is achieved by promoting integrated systems. Such systems include the players, selected synergies, the infrastructures (tangible parts of the offer) and, not least, socio-cultural resources. At the same time, it entails a reorganisation of economic activities, trade, agriculture, forestry. It goes without saying that Italian National Parks play a significant role as promoters of a complex relational system by developing strategies and territorial competition through inclusive processes. Strategies engage people constructively across the boundaries of National Parks to achieve sustainable development (Emerson et al., 2012). In sum, in the context of strategic collaborative governance, the Parks experiments forms of combining conservation and development, economy and ecology, transforming backwardness into development. Accordingly, the National Parks can take paths centred on the inclusion of the participatory community, driven by a clear strategic focus, based on the analysis, knowledge and exploitation of resources, which is aimed to a shared 
path of development (Vurro et al. 2014). Collaborative governance translates into the capacity to bring out pluri-subjectivity. Plans and ideas turn into actions and projects that create socio-economic value.

The city of Venice is administered by the Municipality, which plays an administrative role. The Venice City Council establishes business opening hours, regulates taxation and major public services fees, imposes rules of conduct for residents or tourists. The City of Venice only since 2004 is experiencing the adoption of a Strategic Plan covering Venice and the metropolitan city.

The general objective of the Strategic Plan was to build a city characterised by the high quality of life of its inhabitants - in its relational, working and cultural aspects and by the high quality of its physical and environmental settings.

The predominantly economic strategies identified by the Strategic Plan have been designed to create the conditions for Venice to become an attractive place of living within global competition, as a city capable of giving positive contributions, especially political and cultural, at international level.

The plan has been structured in Strategic and Policy lines. It wants to specific goals to be through the development of policies that are reflected in a multiplicity of individual actions: international city of culture and tourism, high education, research and innovation, a node of logistics excellence, of material production and of services.

At a distance of a decade, the Strategic Plan is now specified in a more detailed strategic articulation with the approval of the Territory Plan (pursuant to Article 15, paragraph 6 of the LR 11/2004 of 30 September 2014 ). And the Climate Plan (Resolution 15/2014 of the Municipal Council) a kind of «manifesto» entitled «Venice Future Climate». In the case of the city of Venice, the strategic planning process did not involve all stakeholders in an inclusive way.

The strategic governance was basically exercised by the municipality, but the involvement of other stakeholders, though necessary and foreseen, was not characterised by substantially collaborative logics, but by a search for convergence towards actions and programs sometimes rich in resistance and therefore lacking in the effects.

Considering how the Cilento, Vallo of Diano and Alburni National Park and the city of Venice focus their attention on their specific territorial identity domain we can observe that the two cases are differently caracterised.

The Cilento, Vallo of Diano and Alburni National Park and Venice city develop strategic pathways that are characterised in a different way.

The construction of a territorial identity of the Cilento, Vallo of Diano and Alburni National Park comes out of a process of integration that goes from below and is later integrated into a process in which the social involvement of the various stakeholders is not preordered but is configured during the action. In particular, the process of local integration has a complex character and can be explained as an effect of the interaction of businesses and other local actors in a series of network services, each of which facilitates a different kind of integration. The territorial competition according to the relational perspective, is based on the adoption of a unique and unified identity and the involvement and the synergistic cooperation of all forces, as well as coordination and collaboration among the actors that operate in the area. In the Park area it is possible to have a look at the future clutching the past, projecting the area, emphasising the history, traditions, flavours, fragrances and any other resources, which can lead to a specific recognition. In the case of Cilento, Vallo of Diano and Alburni National Park, the territorial identity domain is the strong point 
on which the competitive positioning of the Park destination is built. The rediscovery of villages, ancient crafts, nature trails and traditions are some of the tangible and intangible resources made available through an inclusion path that connects Park residents with tourists who experience participatory social experiences and who perceive that every element of the Park's offer system is linked to everyone else and represents the common good to be protected and valued.

In the strategic plan of Venice, rather than territorial identity, reference is made to the search for an excellence that somehow seems to want to recall ancient primates. For many centuries Venice has been an exceptional example of human settlement and occupation of the land directly and materially linked to events, traditions, artistic and literary works. The current strategic orientation pathway does not focus on the fact that Venice is currently experiencing a period of deep social crisis.

As it is well-known in Venice, there is a clear decrease in the number of inhabitants. Thanks of a group of citisens, a counter is placed in a showcase of a pharmacy in the historic center, where the number of inhabitants is continually updated and shows that the population is rapidly declining (Tuniz, 2014).

Venice is a city with a century-old identity where everything is organised for the masses of tourists passing through, and cannibalising itself as a tourist attraction. Venice appears as a theatrical city, has failed to regain its history, traditions and knowledge.

The Venice crisis is a crisis of the social space of life as a commitment and a participatory relationship (Settis, 2014). It has assumed characteristics different from the past, lost its identity by increasingly turning into a property, hotel and hospitality property for tourists who no longer belong to the Venetians, with the obvious consequences of drop of population.

Also considering how Cilento, Vallo of Diano and Alburni National Park and city of Venice see the territorial identity domain as a common the two cases present two different situations. Considering the theory of commons, the Cilento, Vallo of Diano, and the Alburni National Park is an example of sharing the local community with a strategic identity based on sustainable tourism development and on a pathway of local community involvement. National Park has focused its strategy developing and renewing the strategic resources of the local actors (both public and private) that operate inside the Park. The key implication of this strategy is that local firms are competing not only on their ability to activate and exploit their existing resources and organisational capabilities, but also on their capability to renew and develop them. Having considered and analysed local development of this territorial area, we observe that firms possess strong organisational routines for renewing these resources and organisational capabilities. In this direction, competitive advantage originates from the creative integration and subsequent exploitation of commons resources in the Park area . The social relationship that exists between those who live and promotes a territorial context is the factor that animates places that speak of history, traditions, who transmit knowledge and value architecture. It is the social relationship that gives a meaning to a place that becomes the common of those who live there. In Venice the problem is to regain social energies. Venice is today submerged by tourists, while the number of Venetians living in Venice has dropped enormously.

Venetian citisens, associations and committees are working but there are still no mechanisms to make the community of Venetians perceive the value of the territory as a common. These are initiatives of individual groups that do not come into mutual relation but tend to pursue their own and selected goals. Several movements have 
been created in the city that have laid the foundations for the protection of Venice, but over the years the initiatives have failed to change the strategic orientation characterised by growing tourist flows, excessive transit of cruise ships, major works and corruptio.

\section{Discussion and Conclusion}

The theoretical analysis has linked the issue of commons good to the issue of territorial governance and territorial identity domain. Although research is still in an exploratory phase, this is a contextualisation that is proposed as innovative. On the level of managerial implications, it is interesting to discuss the presence of Ostrom's design principles in the cases examined. The design principles are elements helping us explain the success of preserving collective resources and favoring the emergence of common territorial identity logical sharing (Ostrom 1990). The used qualitative method resumes what Ostrom pursued when examining selected contexts. The choice of cases is influenced by two territorial systems recognised as UNESCO World Heritage sites.

In the case of Cilento, Vallo of Diano and Alburni National Park, we observe that different principles of collective action can be found. The systemic nature of Cilento, Vallo of Diano and Alburni National Park consists of components characterised by effective governance models, able to guarantee the flexibility of innovative local systems which is currently developed.

Differents actors interact and usually play a decisive role by promoting services capable of understanding and interpreting the economic development and by initiating collaborations characterised by processes of negotiation and settlement (Garlato, 2007).

The Park makes the whole system collaborative, encouraging a proactive approach as well as the coordination between regional actors and public bodies. The actions should be viewed in the light of shared actions and understood within the ecosystem context, where such actions would not otherwise be taken by individuals or organisations.

The case study of Venice city points out that the strategic path is activated by the municipal government but it encounters obstacles to the implementation and involvement of the main stakeholders.

The territorial program, in fact, in spite in recent years it has been attentive to the issues of sustainability and quality of life, it is lacked of a collective governance. The municipal government seeks to find a prevalent role, but it suffers from as strong economic interest and it cannot guarantee a shared and sustainable development path.

In fact, the city of Venice should start a concrete path of deconstruction of the old town, focusing on the typicalness and traditions valorisation. This path would be achieved through a broad involvement of all main stakeholders, especially made up of associations or groups of craftsmen, who should apply to each other's logical organisational logic consistent with the design principles of Ostrom.

In case of Cilento, Vallo of Diano and Alburni National Park, some principles of Ostrom design are applied, while in case of the city of Venice, the Ostrom principles are not applied. In particular, according to the principle number 1 of the Cilento Vallo di Diano and the Alburni National Park, the territory is clearly defined by the Park area for which a naturalistic vocation is shared. 
For the city of Venice, the territorial area is not clearly defined. On the one hand, there is a big area to cover in the currently marginal areas of tourism, but on the other hand, it is considered a very limited territorial area coinciding with the historical center.

This is a particularly critical design principle. The boundaries refer to the physical context. This includes the community involved in the government of the common resource. In the case of Cilento, Vallo of Diano and Alburni National Park, operators belong to a community that shares the same values. In case of Venice, there are, on the one hand, some large international holdings that have important economic interest, and, on the other hand, many small entrepreneurs acting on their own. When Venice is in question, the concept of city as a community territorial system escapes from a clear identification of context features.

Regarding the principle number 2, Cilento, Vallo of Diano and Alburni National Park apply shared standards in the field of territorial protection and sustainability. The exploitation of the territory is managed by principles that are respected in a view of sustainable development as well as the applied sanctions.

Table 2: Organisational Principles of Ostrom's Theory Applied to Cases Studies

\begin{tabular}{|c|c|c|}
\hline Design Principles & $\begin{array}{c}\text { Cilento, Vallo of Diano and } \\
\text { Alburni National Park }\end{array}$ & City of Venice \\
\hline $\begin{array}{c}\text { 1. Define clear group } \\
\text { boundaries. }\end{array}$ & Yes & No \\
\hline $\begin{array}{l}\text { 2. Match rules governing use } \\
\text { of common goods to local } \\
\text { needs and conditions. }\end{array}$ & Yes & No \\
\hline $\begin{array}{l}\text { 3. Ensure that those affected } \\
\text { by the rules can participate in } \\
\text { modifying the rules. }\end{array}$ & Yes & No \\
\hline $\begin{array}{l}\text { 4. Develop a system, carried } \\
\text { out by community members, } \\
\text { for monitoring members' } \\
\text { behavior. }\end{array}$ & No & No \\
\hline $\begin{array}{l}\text { 5. Use graduated sanctions for } \\
\text { rule violators. }\end{array}$ & No & No \\
\hline $\begin{array}{l}\text { 6. Provide accessible, low-cost } \\
\text { means for dispute resolution }\end{array}$ & No & No \\
\hline $\begin{array}{l}\text { 7.Make sure the rule-making } \\
\text { rights of community members } \\
\text { are respected by outside } \\
\text { authorities. }\end{array}$ & Yes & No \\
\hline $\begin{array}{l}\text { 8.Build responsibility for } \\
\text { governing the common } \\
\text { resource in nested tiers from } \\
\text { the lowest level up to the } \\
\text { entire interconnected system. }\end{array}$ & Yes & No \\
\hline
\end{tabular}

Source: Our elaboration

In case of Venice, there are some rules imposed by the administrative authorities and sanctioned with fines. There are no shared principles.

One of the main critical aspects is the excessive theatricality and absence of an 
authentic culture. Those who work on the territory, mostly gift extraneous to the territory. There is a tendency to maximise individual interests.

The lack of shared principles of territorial protection stem from appointees that are not involved in the choices affecting the territory. While in the Cilento, Vallo of Diano and Alburni National Park there is a government body called the Community of the Park that is involved in many choices of sustainable development. In Venice, the operator's or citisen committees have an advisory role, but they are not the expression of shared intentions (design principle $n{ }^{\circ} 3$ ). In the city of Venice, there were not meetings to share rules and behaviors.

The design principles No. 4 and 5 refer to the monitoring rules and system of sanctions for those who break the rules governing the territory in a community logic. In Cilento, Vallo of Diano and Alburni National Park, and in the city of Venice the spirit of identity and the logic of self-government are not so much pushed as to frame monitoring and any sanctions in an intelligently organised system.

The frame for the Cilento, Vallo of Diano and Alburni National Park should be proud of the emergence of self-organised groups that mutually control behavior and tackle serious issues such as wild boar or hunting problems. The city of Venice must implement the previous design principles first. In both cases no conflict resolution mechanisms were envisaged.

Regarding Principle 7 and 8 in case of the Cilento Vallo of Diano and Alburni National Park, the Park's administrative authority respects and fosters compliance with the provisions of the agreement, favoring the interlinking of the the territorial area government and commons between the nested institutions.

In absence of commonality logic in the government of Venice it is not possible to detect the presence of these design principles.

The application of the design principles of Ostrom in territorial area can become a fruitful field of openness towards new governance models.

The design principles can be configured as a set of operational rules to determine what procedures must be followed, what information should be exchanged, which strategies can be implemented to favor a co-evolutionary development of the territories.

Managerial studies were mostly focused on possible application models of competitive logic to the territory.

The exploratory study of the cases of the Cilento Vallo di Diano and Alburni National Park and the City of Venice conducted with reference to the identification of Ostrom Theory design principles can help us to identify how territories can support the development process of a shared community identity.

The territorial co-evolutionary development process focuses on the territorial community and it is characterised by the fact that the territorial development involves all actors that are in the enjoyment system, both on the supply side and on the demand side.

From the managerial perspective, the paper shows that it is necessary to introduce decision-making paths based on inclusive logic. Operationally, it is possible to provide a co-evolutionary development, favoring the presence of the governance systems of common goods.

On theoretical level, it appears innovative to introduce cultural contaminations in the territorial governance models.

Considering the territorial as a common good and emphasizing geographical and cultural aspects in particular, as well as people and the territorial knowledge, it is 
possible to open to governance models that are not based on managerial logic.

The dual value of geographic and cultural structure and knowledge of places and people are the elements that open up to government hypotheses.

For these reasons, the design principles of Ostrom can be a very interesting area of research on the topic of governance of goods recognised as common ones by related subjects and in the territorial governance.

\section{Bibliography}

Agrawal, A. \& Lemos, M. C. (2007). A Greener Revolution in the Making?: Environmental. In Governance in the 21st Century. Environment, 49(5) 36-45.

http://dx.doi.org/10.3200/ENVT.49.5.36-45

Albert, S., Ashforth, B. E. \& Dutton, J. E. (Eds.) (2000). Organisational identity and identification: charting new waters and building new bridges, in Academy of Management Journal, 25, 13-17. http://dx.doi.org/10.5465/AMR.2000.2791600

Ashforth, B. \& Mael, F. (1996). Organisational identity and strategy as a context for the individual, in Advances in Strategic Management, 13, 19-64.

Baskarada, S. (2014). Qualitative case study guidelines. Browser Download This Paper.

Baxter, P., \& Jack, S. (2008). Qualitative Case Study Methodology: Study Design and Implementation for Novice Researchers .The Qualitative Report, 13(4), 544-559.

Bellini, N. (2004). Territorial governance and area image. Symphonya. Emerging Issues in Management, 1, 14-26.

http://dx.doi.org/10.4468/2004.1.03bellini

Brondoni, S. M., (2011). Global Networks, Knowledge Management and World Cities, Symphonya. Emerging Issues in Management (symphonya.unimib.it), 1, 7-18.

http://dx.doi.org/10.4468/2011.1.02brondoni

Brondoni, S. M. \& Franzoni S (2016).Ouverture de 'Market-Driven Management in Global Tourism' Symphonya. Emerging Issues in Management, 2, 1-6.

http://dx.doi.org/10.4468/2016.2.01ouverture

Brown C. (2001). Globalisation, borders and identity. In: Albert, M., Jacobson, D. and Lapid, Y. eds. Identities, border, orders: rethinking international relations theory eds. Minneapolis: University of Minnesota, 117-137.

Bryson, J. M., Crosby, B. C. \& Stone, M. M. (2006). The design and implementation of cross-sector collaborations: Propositions from the literature. Public administration review, 66, 44-55.

http://dx.doi.org/10.1111/j.1540-6210.2006.00665.x

Brunetti, F. (2002). Il destination management: Aspetti problematici, significato e percorsi alla ricerca di una qualità ad effetto prolungato. In M. Franch (Ed.), Destination management: governare il turismo tra locale e globale (pp. 39-64). Torino, Italy: Giappichelli.

Buhalis, D. (2000). Marketing the competitive destination of the future. Tourism Management, 21(1), $97-116$.

http://doi.org/10.1016/S0261-5177(99)00095-3

Butler R.W. (1980). The concept of a tourist area cycle of evolution: implications for management of resources, Canadian Geographier, XXIV, (1).

http://dx.doi.org/10.1111/j.1541-0064.1980.tb00970.x

Corti, A., (2016). Global Tourism New Volatility, Old Statistics, Symphonya. Emerging Issues in Management (symphonya.unimib.it), 1, 25-30.

http://dx.doi.org/10.4468/2016.1.03corti

Dutton, J. E., \& J. M. Dukerich. (1991). Keeping an eye on the mirror: Image and identity in organisational adaptation, Academy of Management Journal, 34, 517-554. 
http://dx.doi.org/10.2307/256405

Emerson K., T. Nabatchi \& S. Balogh. (2012). An Integrative Framework for Collaborative Governance. Journal of Public Administration, Research and Theory.

http://dx.doi.org/10.1093/jopart/mur011

Fiol, C. M. (1991). Managing culture as a competitive resource: An identity-based view of sustainable competitive advantage, Journal of Management, 17, 191-211.

https://doi.org/10.1177/014920639101700112

Fiol, C. M. (2001). Revisiting an identity-based view of sustainable competitive advantage, Journal of Management, 27, 691-699.

https://doi.org/10.1177/014920630102700606

Flyvbjerg, B. (2006). Five misunderstandings about case-study research. Qualitative inquiry, 12(2), 219-245.

https://doi.org/10.1177/1077800405284363

Gioia, D. A. \& Thomas, J. B. (1996). Identity, image, and issue interpretation: Sensemaking during strategic change in Academia, Administrative Science Quarterly, 41(3) 370-394.

Haveri A. (2006). Complexity in Local Government Change: Limits to Rational Reforming, Public Management Review, 8(1) 31-46

http://dx.doi.org/10.1080/14719030500518667

Lanza A. (2000), Knowledge Governance, Egea, Milano.

Livengood R. S., Reger R.K. (2010), That's our turf! Identity domains and competitive dynamics, in Academy of Management Review, 35(1) 48-66.

http://www.jstor.org/stable/27760040

Manfredi, F. (2013). Community Governance. Comunità inflazione. Cacucci Editore.

Olson, M. (1965). The logic of collective action: Public goods and the theory of groups. Cambridge, MA: Harvard University Press.

Ostrom, E. (1990). Governing the commons: The evolution of institutions for collective action. New York, NY: Cambridge University Press.

Ostrom, E. (1998). Institutional analysis, design principles, and threats to sustainable community governance and management of commons. In E. Berge, \& N. C. Stenseth (Eds.), Law and the governance of renewable resources: Studies from Northern Europe and Africa (pp.27-53). Oakland, CA: ICS Press.

Ostrom, E. (2009). A general framework for analyzing sustainability of social-ecological systems. Science, 325(5939), 419-422.

http://dx.doi.org/10.1126/science.1172133

Pattanaro, G., \& Pistocchi, F. (2016). Linking Destinations Through Sustainable Cultural Routes. Symphonya. Emerging Issues in Management, (1), 83.

http://dx.doi.org/10.4468/2016.1.08pattanaro.pistocchi

Presenza, A., Sheehan, L., \& Ritchie, J. B. (2005). Towards a model of the roles and activities of destination management organisations. Journal of Hospitality, Tourism and Leisure Science, 3(1), $1-16$.

Roca, Z., \& de Nazaré Oliveira-Roca, M. (2007). Affirmation of territorial identity: A development policy issue. Land Use Policy, 24(2), 434-442.

https://doi.org/10.1016/j.landusepol.2006.05.007

Salvioni, D.M., \& Astori, R. (2013) Sustainable Development and Global Responsibility in Corporate Governance, Symphonya. Emerging Issues in Management (symphonya.unimib.it), 1, 1-25.

http://dx.doi.org/10.4468/2013.1.03salvioni.astori

Settis, S. (2014). In whose name do we act? Protecting future generations through commons, (26), 27.

Seawright, J., \& Gerring, J. (2008). Case selection techniques in case study research: A menu of qualitative and quantitative options. Political Research Quarterly, 61(2), 294-308.

https://doi.org/10.1177/1065912907313077

Seawright, J. (2016). The case for selecting cases that are deviant or extreme on the independent 
variable. Sociological Methods \& Research, 45(3), 493-525.

https://doi.org/10.1177/0049124116643556

Vurro, C., Russo, A., \& Costanzo, L. A. (2014). Sustainability along the value chain: collaborative approaches and their impact on firm performance. Symphonya. Emerging Issues in Management (symphonya.unimib.it), 1, 30-44.

http://dx.doi.org/10.4468/2014.2.04vurro.russo.costanzo

Whetten, D. A. \& Godfrey, P.C. (1998). Identity in organisations: Building theory through conversations. Thousand Oaks, CA: Sage.

Yin, R. K. (2003). Case Study Research: Design and Methods. Edition.

Zan, L., \& Baraldi, S. B. (2013). The heritage chain management. General issues and a case study, China. Journal of cultural heritage, 14(3), 211-218.

https://doi.org/10.1016/j.culher.2012.06.007 